\title{
Feasibility of breeding male-sterile populations for use in developing inter- population hybrids of pearl millet
}

\author{
K. N. RAI ${ }^{1}$, D. J. ANDREWS ${ }^{2}$ and A. S. RAO \\ ${ }^{1}$ Genetic Resources and Enhancement Program, International Crops Research Institute for the Semi-Arid Tropics \\ (ICRISAT), Patancheru 502 324, Andhra Pradesh, India; ${ }^{2}$ Department of Agronomy, University of Nebraska, Lincoln, NE \\ 68583-0519, USA
}

With 5 tables

Received March 30, 1999/Accepted February 4, 2000

Communicated by H. H. Geiger

\begin{abstract}
Inter-population hybrids of pearl millet, Pennisetum glaucum (L.) R. Br., have a substantial grain yield advantage over open-pollinated varieties that makes them an appropriate and economically viable proposition for many African agricultural situations, provided that stable male-sterile populations can be developed for use as seed parents. The objective of this research was to examine the feasibility of breeding stable male-sterile populations, using the $d_{2}$ dwarf version of Nigerian Composite $\mathrm{NCD}_{2}$ and the $\mathrm{A}_{4}$ cytoplasmic-nuclear male sterility system as a test case. Results showed that two cycles of recurrent selection for sterility maintenance ability led to the development of a fully effective maintainer version of $\mathrm{NCD}_{2}$. There was no significant difference between the original $\mathrm{C}_{0}$ cycle bulk and the $\mathrm{C}_{3}$ cycle bulk (developed from the third and final cycle of recurrent selection) for grain yield and other agronomic traits. The male-sterile population at the third backcross stage, developed from the maintainer version of $\mathrm{NCD}_{2}$, had as high a level of stable male sterility as the $A_{1}$ system commercial inbred male-sterile line $841 \mathrm{~A}_{1}$. Thus, it is concluded that with the use of the $\mathrm{A}_{4}$ cytoplasmic male-sterile system, it would be possible rapidly to develop a maintainer version of any population without detrimental effects on grain yield and agronomic traits. Male sterility of populations developed from these maintainers will be highly stable, paving the way for their effective utilization as seed parents in breeding inter-population hybrids.
\end{abstract}

Key words: Pennisetum glaucum - inter-population hybrid male-sterile population — recurrent selection

Pearl millet is a highly cross-pollinated crop with $75-80 \%$ natural outcrossing (Burton 1974). An extensive survey of pearl millet literature showed $40 \%$ average better-parent heterosis for grain yield, ranging from -57 to $424 \%$ (Virk 1988). These two features of the crop satisfy some of the basic requirements for the exploitation of heterosis in cultivar development. Commercial exploitation of heterosis in pearl millet only became possible with the development of a cytoplasmic-nuclear malesterile line Tift 23A in the USA (Burton 1965). The first singlecross grain hybrid (HB-1) based on this male-sterile line, released in India in 1965, outyielded improved local open-pollinated varieties (OPVs) by as much as $100 \%$ (Athwal 1965). The extent of grain yield advantage and release of HB-1 stimulated substantial pearl millet grain hybrid research and development activity in India. As a result, more than 18 hybrids are now grown on varying scales, covering more than half of the $10 \times 10^{6}$ ha area under pearl millet in India, and doubling the grain yield over the pre-hybrid era (Rai et al. 1997).
Single-cross hybrids may not provide a good starting point for the exploitation of heterosis in hybrid cultivars in much of Africa, especially western Africa. There are three main reasons for this contention. First, genetic uniformity of single-cross hybrids makes them more vulnerable to downy mildew, Sclerospora graminicola (Sacc.) J. Schröt., epidemics, as has repeatedly happened in India (Hash 1997; Hash et al. 1997; Rai et al. 1997). This problem is likely to be more challenging in western Africa where downy mildew pathotypes have been shown to be relatively more virulent than those in much of India (Singh et al. 1997). Single-cross hybrids, especially those based on cytoplasmic male-sterile (CMS) lines, will face additional challenges from smut, Moesziomyces penicillariae (Bref.) Vànky, and ergot, Claviceps fusiformis Loveless, which are more severe in parts of Africa than in India. Second, pearl millet displays a high degree of inbreeding depression. Thus, if seed production is undertaken in the main crop season, characterized by relatively harsher environmental conditions, inbred lines of single-cross hybrids would have poor emergence and vigour, leading to economically unacceptable seed yields in the hybrid seed production plots. Third, inbred parents of single-cross hybrids take considerable time and research investment for development and testing, and the material and manpower resources in the African regions are inadequate to undertake such activities. Thus, the immediate alternative could be to use existing improved OPVs as male parents to breed inter-population hybrids on malesterile populations, which would address all three issues mentioned above. Because of their adaptation and acceptance by farmers, successful OPVs would make good hybrid parents for interpopulation hybrids, thus further capitalizing on OPV breeding. Improved OPVs are already being used as pollen parents to breed topcross hybrids of pearl millet for African agricultural situations (Anand Kumar et al. 1999).

Commercial success of inter-population hybrids would depend on the extent of their grain yield advantage over OPVs, and the feasibility of breeding male-sterile populations. Preliminary results from western Africa have shown interpopulation hybrids outyielding their improved OPV parents by 27-59\% (Lambert 1983) and 32-45\% (Ouendeba et al. 1993). This level of grain yield advantage is of significant value for commercial viability of inter-population hybrids. The feasibility of breeding a male-sterile population would depend on selection efficiency for sterility maintenance ability in the seed parent population. Recurrent selection has not been found to be effec- 
tive in rapid development of maintainer versions of populations with respect to the $A_{1}$ CMS system. A composite developed from diverse maintainers of the $\mathrm{A}_{1}$ system A-lines produced $<30 \%$ fully sterile testcrosses when tested on the male-sterile line $5141 \mathrm{~A}_{1}$. Less than $60 \%$ of the testcross progenies derived even from the $\mathrm{C}_{2}$ bulk of this population were sterile when crossed on the same tester line (K. N. Rai, unpublished data). Aken'Ova (1982) conducted six cycles of recurrent selection in a maiwa population, using Tift $23 \mathrm{~A}_{1}$ as a tester, but did not report on the extent of genetic improvement in sterility maintenance ability of the improved cycle bulks. An alternative CMS system, designated as $\mathrm{A}_{4}$ (Hanna 1989), has more stable male sterility and this sterility is less influenced by environmental factors than that of the $\mathrm{A}_{1}$ system (Andrews and Rajewski 1994, Rai et al. 1996). The objective of this research was to examine the feasibility of breeding stable male-sterile populations, using the $d_{2}$ dwarf version of Nigerian Composite $\mathrm{NCD}_{2}$ (Rai et al. 1995a) and the $\mathrm{A}_{4}$ CMS system as a test case.

\section{Materials and Methods}

Population and CMS tester: The dwarf Nigerian Composite $\mathrm{NCD}_{2}$ of Pennisetum glaucum L. R.B.V., used in this study is a $d_{2}$ dwarf version of a tall Nigerian composite (NC) developed by a sidecar method of limited backcrossing in which successive cycle bulks of the tall NC undergoing recurrent selection were used as a recurrent parent and GAM 73 (a dwarf synthetic from Senegal) as the $d_{2}$ gene donor (Rai 1990). Forty-one dwarf $\mathrm{BC}_{3} \mathrm{~F}_{5}$ progenies derived from this backcross programme were random-mated three times to develop $\mathrm{NCD}_{2}$. In yield trials conducted for 2 years at two locations in southern India, $\mathrm{NCD}_{2}$ was the highest yielding population among the seven tall composites and their respective dwarf versions. $\mathrm{NCD}_{2}$ has a high level of downy mildew resistance and the long panicles typical of many African landraces. It has also been found to have a high level of seedling thermotolerance (Peacock et al. 1993). These traits made $\mathrm{NCD}_{2}$ an idea population, not only for the assessment of the recurrent selection efficiency to convert it into a maintainer version, but also for developing it into a male-sterile population that may have a direct applied value in breeding inter-population hybrids for African conditions, provided that its downy mildew resistance level is comparable to the original Nigerian composite. A dwarf male-sterile line, $81 \mathrm{~A}_{4}$, based on the $\mathrm{A}_{4} \mathrm{CMS}$ system was used as a tester to identify maintainer plants in $\mathrm{NCD}_{2}$ and its selected versions. During the mid-1990s, when the present study was initiated, line $81 \mathrm{~A}_{4}$ had been found to have the most stable male sterility among several isonuclear A-lines with diverse CMS sources, and the largest proportion of plants and progenies from diverse genetic backgrounds were maintainers of this A-line (Rai et al. 1996).

Recurrent selection: Three cycles of recurrent selection were conducted for the improvement of sterility maintenance ability of $\mathrm{NCD}_{2}$. The procedure involved selfing individual plants of $\mathrm{NCD}_{2}$ (to produce $\mathrm{S}_{1}$ seed), as well as crossing those plants onto line $81 \mathrm{~A}_{4}$ (to produce testcrosses), evaluation of testcrosses for their sterility/fertility reaction, and recombining the $\mathrm{S}_{1}$ progenies of those $\mathrm{NCD}_{2}$ plants that produced fully sterile testcrosses. For recombination, pollen collected from all $\mathrm{S}_{1}$ progenies flowering at a given time was bulked and then used for crossing on two or three plants of each of the selected $\mathrm{S}_{1}$ progenies to simulate random mating. This crossing work was deliberately spread over 7-8 days until all the progenies had flowered. The testcrosses, grown in 1-row plots (25-35 plants) during the rainy season, were visually evaluated at $75 \%$ anthesis for male fertility/sterility on the basis of pollen shedding. Testcrosses that had no pollen-shedding (PS) plants were classified as sterile (S), those having predominantly non-PS plants as $\mathrm{S} / \mathrm{F}$, those having predominantly PS plants as $\mathrm{F} / \mathrm{S}$, and those having all plants PS as fertile (F). Segregation for fertility would occur if a testcross involved a $\mathrm{NCD}_{2}$ plant that was heterozygous for a fertility restoration gene. The number of testcrosses evaluated and $S_{1}$ lines recombined in various selection cycles is given in Table 1. The number of $\mathrm{S}_{1}$ progenies recombined in the cycles $\mathrm{C}_{0}$ and $\mathrm{C}_{2}$ were slightly less than the number of sterile testcrosses. In the $C_{1}$ cycle, only about $50 \%$ of those $S_{1}$ progenies that corresponded to sterile testcrosses were recombined.

Composite bulks: The four cycle bulks $\left(\mathrm{C}_{0}-\mathrm{C}_{3}\right)$ of $\mathrm{NCD}_{2}$ were used for two purposes. Their topcross hybrids with $81 \mathrm{~A}_{4}$ were used to evaluate the progress in sterility maintenance ability and the bulks per se were evaluated in a yield trial to examine if recurrent selection for sterility maintenance caused any changes in grain yield and other agronomic traits

Topcrosses were made by crossing the male-sterile line $81 \mathrm{~A}_{4}$ with bulked pollen from 100-120 random plants of each composite bulk The number of topcross plants used for PS assessment during the 1996 and 1997 rainy seasons at Patancheru is given in Table2. Prior to this evaluation, progress in sterility maintenance ability was monitored while recurrent selection continued. For this, equal amounts of seed from all the testcrosses (used as test units for recurrent selection) from each of the $\mathrm{C}_{0}, \mathrm{C}_{1}$ and $\mathrm{C}_{2}$ bulks were pooled to produce 'topcross equivalents', which were evaluated for frequency of male-sterile plants during the course of recurrent selection under various environmental conditions. The number of hybrid plants and the year/season of evaluation are given in Table 3 .

The yield trial of the four cycle bulks was conducted in four-row plots of $4 \mathrm{~m}$ length, replicated eight times in a randomized complete block design during the rainy and post-rainy seasons of 1996 at Patancheru. Grain yield and time to $50 \%$ flowering were recorded on a whole-plot basis. Plant height and panicle length were recorded from the main shoot of 10 random plants, and 1000-seed mass was estimated from a single 200-seed sample for each plot. The number of panicles per plant was determined from plant and panicle count data for each plot. Plot means were used for a fixed model analysis of variance using the Genstat 5 statistical package (Genstat 5 Committee 1993).

Male-sterile population: During the course of recurrent selection, the latest available cycle bulk of $\mathrm{NCD}_{2}$ at the time was crossed and backcrossed into the cytoplasm of $81 \mathrm{~A}_{4}$, following a sidecar method (Rai 1990), to develop a male-sterile version of $\mathrm{NCD}_{2}$. During backcrossing, crosses were made on random male-sterile plants. $\mathrm{A} \mathrm{BC}_{3}$ version of this population (hereafter referred to as $\mathrm{NCD}_{2} \mathrm{~A}_{4}-\mathrm{BC}_{3}$ ), was developed by three backcrosses into the $\mathrm{A}_{4}$ cytoplasmic background. This male sterile population was evaluated for stability of male sterility using two $A_{1}$ system commercial inbred male-sterile lines, $81 \mathrm{~A}_{1}$ (Anand Kumar et al. 1984) and $841 \mathrm{~A}_{1}$ (Singh et al. 1990), as controls.

The trial was conducted in isolated plots at Patancheru during two rainy-season environments and two post-rainy-season environments. The number of plants evaluated for pollen shedding and seedset under selfing bags is given in Table 4. Seedset was scored following the standard rating procedure developed for the fungal disease ergot, C. fusiformis Loveless (Thakur and Williams 1980).

\section{Results}

Recurrent selection was highly effective in improving male sterility maintenance ability of the $\mathrm{NCD}_{2}$ population. The frequency of male-sterile testcross progenies increased from $36 \%$ for the $\mathrm{C}_{0}$ bulk to $88 \%$ for the $\mathrm{C}_{1}$ bulk and $100 \%$ for the $\mathrm{C}_{2}$ bulk (Table 1). The testcrosses that segregated for fertile and sterile plants decreased rapidly from $42 \%$ for the $\mathrm{C}_{0}$ bulk to $7 \%$ for the $\mathrm{C}_{1}$ bulk and $0 \%$ for the $\mathrm{C}_{2}$ bulk. A comparison of topcross hybrids made with four cycle bulks $\left(\mathrm{C}_{0}\right.$ to $\left.\mathrm{C}_{3}\right)$ and evaluated during the 1996 and 1997 rainy seasons confirmed the above improvement in the sterility maintenance ability of $\mathrm{NCD}_{2}$ (Table 2). However, the topcross produced from the $\mathrm{C}_{0}$ bulk had $75.3-77.3 \%$ PS plants, which was significantly higher than expected on the assumption of control of sterility by single recessive gene, as reflected in the frequencies of sterile and 
Table 1: Number of testcrosses $\left(81 \mathrm{~A}_{4} \times \mathrm{S}_{0}\right.$ plants) of three selection cycle bulks of $\mathrm{NCD}_{2}$ in pearl millet and their frequencies in male-sterile (S), segregating $(\mathrm{S} / \mathrm{F}$ and $\mathrm{F} / \mathrm{S})$, and fertile $(\mathrm{F})$ classes, and number of selected $\mathrm{S}_{1}$ lines in the rainy season at Patancheru

\begin{tabular}{|c|c|c|c|c|c|c|c|}
\hline \multirow[b]{2}{*}{ Cycle bulk } & \multirow[b]{2}{*}{ Year } & \multirow{2}{*}{$\begin{array}{c}\text { Number of } \\
\text { testcrosses sown }\end{array}$} & \multicolumn{4}{|c|}{ Testcrosses: frequency $(\%)$ in class } & \multirow[b]{2}{*}{ Number of $S_{1}$ lines selected } \\
\hline & & & $\mathrm{S}$ & $\mathrm{S} / \mathrm{F}$ & $\mathrm{F} / \mathrm{S}$ & $\mathrm{F}$ & \\
\hline $\mathrm{C}_{0}$ & 1992 & 392 & 36 & 14 & 28 & 22 & 131 \\
\hline $\mathrm{C}_{1}$ & 1994 & 152 & 88 & 5 & 2 & 5 & 76 \\
\hline $\mathrm{C}_{2}$ & 1995 & 123 & 100 & 0 & 0 & 0 & 116 \\
\hline
\end{tabular}

${ }^{1}$ Number of $\mathrm{S}_{1}$ lines corresponding to testcross progenies of the $\mathrm{S}$ class that were recombined to produce the succeeding cycle bulk.

Table 2: Number of plants evaluated and frequency of male-sterile plants of topcross hybrids of four $\mathrm{NCD}_{2}$ selection cycle bulks in pearl millet during the 1996 and 1997 rainy season at Patancheru

\begin{tabular}{llrlll}
\hline & \multicolumn{2}{c}{ Total plants $(\mathrm{n})$} & & \multicolumn{2}{c}{ Male-sterile plants (\%) } \\
\cline { 2 - 3 } \cline { 5 - 6 } Topcross hybrid & 1996 & 1997 & & 1996 & 1997 \\
\hline $81 \mathrm{~A}_{4} \times \mathrm{NCD}_{2} \mathrm{C}_{0}$ & 328 & 941 & & 75.3 & 77.3 \\
$81 \mathrm{~A}_{4} \times \mathrm{NCD}_{2} \mathrm{C}_{1}$ & 310 & 1231 & & 95.8 & 99.6 \\
$81 \mathrm{~A}_{4} \times \mathrm{NCD}_{2} \mathrm{C}_{2}$ & 567 & 855 & & 97.7 & 99.8 \\
$81 \mathrm{~A}_{4} \times \mathrm{NCD}_{2} \mathrm{C}_{3}$ & 310 & 637 & & 98.1 & 99.8 \\
\hline
\end{tabular}

Table 3: Frequency of pollen-sterile plants in 'topcross equivalents' of three cycle bulks of $\mathrm{NCD}_{2}$ at Patancheru

\begin{tabular}{cclcc}
\hline Topcross equivalent & Year & Season & Total number of plants & Male-sterile plants (\%) \\
\hline $81 \mathrm{~A}_{4} \times \mathrm{NCD}_{2} \mathrm{C}_{0}$ & 1993 & Cool dry & 229 & 62 \\
& 1994 & Rainy & 214 & 50 \\
& 1995 & Rainy & 214 & 62 \\
$81 \mathrm{~A}_{4} \times \mathrm{NCD}_{2} \mathrm{C}_{1}$ & 1996 & Hot dry & 170 & 59 \\
& 1994 & Rainy & 430 & 91 \\
$81 \mathrm{~A}_{4} \times \mathrm{NCD}_{2} \mathrm{C}_{2}$ & 1995 & Rainy & 190 & 93 \\
& 1996 & Hot dry & 1058 & 99 \\
& 1995 & Rainy & 220 & 100 \\
\hline
\end{tabular}

Table 4: Grain yield and other agronomic traits of four cycle bulks of $\mathrm{NCD}_{2}$ in pearl millet; means across the 1996 rainy and dry seasons at Patancheru

\begin{tabular}{lcccccc}
\hline Cycle bulk & $\begin{array}{c}\text { Grain yield } \\
(\mathrm{t} / \mathrm{ha})\end{array}$ & $\begin{array}{c}\text { Days to } 50 \% \\
\text { flowering }\end{array}$ & $\begin{array}{c}\text { Plant height } \\
(\mathrm{m})\end{array}$ & $\begin{array}{c}\text { Panicle length } \\
(\mathrm{cm})\end{array}$ & $\begin{array}{c}\text { Number of tillers } \\
\text { per plant }\end{array}$ & $\begin{array}{c}1000 \text {-seed mass } \\
(\mathrm{g})\end{array}$ \\
\hline $\mathrm{C}_{0}$ & 1.96 & 52.8 & 1.51 & 34.1 & 1.13 & 7.33 \\
$\mathrm{C}_{1}$ & 1.45 & 58.1 & 1.43 & 33.6 & 1.13 & 6.67 \\
$\mathrm{C}_{2}$ & 1.80 & 55.7 & 1.50 & 33.8 & 1.13 & 7.10 \\
$\mathrm{C}_{3}$ & 1.83 & 53.4 & 1.54 & 33.3 & 1.18 & 7.08 \\
LSD $_{0.05}$ & \pm 0.16 & \pm 0.6 & \pm 0.06 & \pm 1.1 & \pm 0.06 & \pm 0.28 \\
\hline
\end{tabular}

segregating testcross progenies observed during recurrent selection. The frequency of PS plants in the 'topcross equivalent' made with the $\mathrm{C}_{0}$ bulk ranged from $50 \%$ in the 1994 rainy season to $62 \%$ in the 1993 dry season (Table 3), giving an average of $58 \%$, which is similar to $57 \%$ PS plants that could be expected from the testcross data (all sterile and $50 \%$ of the segregating testcrosses), assuming control of sterility by a single recessive gene. A similar close correspondence was observed for the $\mathrm{C}_{1}$ and $\mathrm{C}_{2}$ cycles.

Recurrent selection for sterility maintenance ability in $\mathrm{NCD}_{2}$ had no significant effect on grain yield and other agronomic traits of $\mathrm{C}_{2}$ and $\mathrm{C}_{3}$ cycle bulks. The $\mathrm{C}_{1}$ cycle bulk, however, had significantly lower grain yield and 1000 -seed mass, shorter plants and delayed flowering compared with the $\mathrm{C}_{0}$ bulk (Table 4)

A male-sterile population at the $\mathrm{BC}_{3}$ stage of its development should be identical to its recurrent parent with respect to nuclear gene(s) responsible for male sterility, assuming simple inheritance and no complication by modifiers. Thus, sterility evaluation in a male-sterile backcross population at $\mathrm{BC}_{3}$ should permit assessment of the sterility level expected in the final male-sterile population. In the absence of a commercial $\mathrm{A}_{4^{-}}$ system A-line, the commercial viability of such a would-be male-sterile population was tested by comparing the sterility of $\mathrm{NCD}_{2} \mathrm{~A}_{4}-\mathrm{BC}_{3}$ with two widely used commercial $\mathrm{A}_{1}$-system male-sterile lines $\left(81 \mathrm{~A}_{1}\right.$ and $\left.841 \mathrm{~A}_{1}\right)$. Male sterility of $\mathrm{NCD}_{2} \mathrm{~A}_{4}$ 
Table 5: Frequency of pollen shedders and distribution of seedset in the $\mathrm{BC}_{3}$ population of $\mathrm{NCD}_{2}$ with $\mathrm{A}_{4}$ cytoplasm $\left(\mathrm{NCD}_{2} \mathrm{~A}_{4}-\mathrm{BC}_{3}\right)$ and in $\mathrm{CMS}$ control lines $81 \mathrm{~A}_{1}$ and $841 \mathrm{~A}_{1}$ during the 1996 and 1997 rainy and dry seasons at Patancheru

\begin{tabular}{|c|c|c|c|c|c|c|c|c|c|}
\hline \multirow[b]{2}{*}{ Population/line } & \multirow[b]{2}{*}{ Season $^{1}$} & \multicolumn{2}{|c|}{ Male sterility } & \multicolumn{6}{|c|}{ Seedset under selfing bags: per cent plants in seedset class } \\
\hline & & $\begin{array}{c}\text { Total plants } \\
\text { (n) }\end{array}$ & $\begin{array}{c}\text { Pollen shedders } \\
(\%)\end{array}$ & $\begin{array}{l}\text { Total plants } \\
\text { (n) }\end{array}$ & 0 & $1-5$ & $6-20$ & $21-50$ & $51-100$ \\
\hline \multirow{5}{*}{$\mathrm{NCD}_{2} \mathrm{~A}_{4}-\mathrm{BC}_{3}$} & Rainy 96 & 1431 & 1.0 & 539 & 91.3 & 5.6 & 1.3 & 0.7 & 1.1 \\
\hline & Hot Dry $97 \mathrm{~F}$ & 1067 & 0.2 & 398 & 97.7 & 1.5 & 0.5 & 0.3 & 0.0 \\
\hline & Hot Dry $97 \mathrm{M}$ & 1033 & 0.1 & 349 & 100.0 & 0.0 & 0.0 & 0.0 & 0.0 \\
\hline & Rainy 97 & 568 & 0.5 & 419 & 97.9 & 1.7 & 0.2 & 0.2 & 0.0 \\
\hline & Overall & 4099 & 0.5 & 1705 & 96.7 & 2.2 & 0.5 & 0.3 & 0.3 \\
\hline \multirow[t]{5}{*}{$81 \mathrm{~A}_{1}$ (control) } & Rainy 96 & 1618 & 0.6 & 599 & 97.8 & 2.2 & 0.0 & 0.0 & 0.0 \\
\hline & Hot Dry $97 \mathrm{~F}$ & 1200 & 0.3 & 483 & 95.7 & 3.9 & 0.4 & 0.0 & 0.0 \\
\hline & Hot Dry $97 \mathrm{M}$ & 1066 & 0.0 & 393 & 98.7 & 1.0 & 0.3 & 0.0 & 0.0 \\
\hline & Rainy 97 & 785 & 0.1 & 487 & 98.8 & 1.2 & 0.0 & 0.0 & 0.0 \\
\hline & Overall & 4669 & 0.3 & 1962 & 97.8 & 2.1 & 0.2 & 0.0 & 0.0 \\
\hline \multirow[t]{5}{*}{$841 \mathrm{~A}_{1}$ (control) } & Rainy 96 & 1119 & 1.0 & 513 & 93.4 & 4.9 & 1.5 & 0.2 & 0.0 \\
\hline & Hot Dry $97 \mathrm{~F}$ & 1333 & 0.2 & 714 & 97.7 & 2.0 & 0.3 & 0.0 & 0.0 \\
\hline & Hot Dry $97 \mathrm{M}$ & 1216 & 0.2 & 318 & 98.7 & 0.6 & 0.6 & 0.0 & 0.0 \\
\hline & Rainy 97 & 985 & 0.4 & 622 & 96.6 & 2.7 & 0.5 & 0.2 & 0.0 \\
\hline & Overall & 4653 & 0.5 & 2167 & 96.6 & 2.6 & 0.7 & 0.1 & 0.0 \\
\hline
\end{tabular}

${ }^{1} \mathrm{~F}=$ February planting; $\mathrm{M}=$ March planting.

$\mathrm{BC}_{3}$ was as high and stable as that of $841 \mathrm{~A}_{1}$. Line $81 \mathrm{~A}_{1}$ was only marginally better, especially in the $6-20 \%$ and $21-50 \%$ seedset classes (Table 5). Generally, all three had $<1 \%$ PS plants, and $>96 \%$ of the non-PS plants set no seed. In each of the three seedset classes $(1-5 \%, 6-20 \%$ and $21-50 \%)$, sterility of $\mathrm{NCD}_{2} \mathrm{~A}_{4}-\mathrm{BC}_{3}$ was similar to that of $841 \mathrm{~A}_{1}$, except that $\mathrm{NCD}_{2} \mathrm{~A}_{4}-\mathrm{BC}_{3}$ had $1.1 \%$ plants in the $51-100 \%$ seedset class while $81 A_{1}$ and $841 A_{1}$ had none. In the 1997 rainy season, 591 $\mathrm{NCD}_{2} \mathrm{~A}_{4}-\mathrm{BC}_{6}$ plants were also evaluated for PS and seedset. There were no PS plants, $91.7 \%$ of the selfed plants had no seedset, $7.6 \%$ of the plants were in the $1-5 \%$ seedset class and the remaining $0.7 \%$ were in the $6-20 \%$ class (data not presented). This indicated that there was a marginal improvement in the sterility of $\mathrm{NCD}_{2} \mathrm{~A}_{4}-\mathrm{BC}_{6}$ compared with that of the $\mathrm{NCD}_{2} \mathrm{~A}_{4}-\mathrm{BC}_{3}$.

\section{Discussion}

A rapid change in the frequency of male-sterile testcrosses from $36 \%$ for the $\mathrm{C}_{0}$ bulk to $100 \%$ for the $\mathrm{C}_{2}$ bulk of $\mathrm{NCD}_{2}$ population indicated that two cycles of recurrent selection were effective in developing its completely maintainer version. It should be noted that most of this progress was made in the first selection cycle. Since $S_{1}$ progenies of only those plants from the $\mathrm{C}_{0}$ bulk that had produced sterile testcrosses were recombined into the next cycle, a low frequency of fertile testcrosses $(5 \%)$ and segregating testcrosses $(7 \%)$ for the $C_{1}$ bulk was unexpected, assuming single recessive gene control of the $\mathrm{A}_{4}$ system of male sterility (Du et al. 1996). This implies that either the genetic control of $\mathrm{A}_{4} \mathrm{CMS}$ system involves more than one gene, including modifiers, or that environmental effects caused some of the potentially segregating testcrosses to express as fully sterile. Another possibility is that for testcross units of 25-35 plants with the pollen-shedding data taken at $75 \%$ anthesis, it is likely that a low frequency of potentially segregating testcrosses consisted of only male-sterile plants, and hence such testcrosses were misclassified as fully sterile. Multi-environment evaluation of testcrosses would minimize such misclassification if the environmental effects were significant and using a larger size of testcross units would minimize this problem if the number of plants in testcross units were inadequate.

While conducting selection for male sterility maintenance ability, it is important to ensure that no undesirable changes take place in the population during the course of recurrent selection. Although the final two-cycle bulks $\left(\mathrm{C}_{2}\right.$ and $\left.\mathrm{C}_{3}\right)$ of the $\mathrm{NCD}_{2}$ did not differ significantly from the $\mathrm{C}_{0}$ bulk for grain yield and other agronomic traits evaluated in this study, the $\mathrm{C}_{1}$ cycle bulk was significantly different from the $\mathrm{C}_{0}$ bulk with respect to grain yield, time to flowering, plant height and 1000seed mass. This suggests the possibility of genetic changes in the populations for non-target traits, which should be carefully monitored during the course of recurrent selection.

The maximum certifiable pollen shedders permitted in pearl millet is $0.05 \%$ in the foundation seed production plots of $\mathrm{A}$ lines and $0.1 \%$ in the certified seed production plots of hybrids (Chopra et al. 1999). An $\mathrm{A}_{4}$-system male-sterile line $81 \mathrm{~A}_{4}$ has been found not to produce any pollen shedders (i.e. complete sterility) across a range of environments (unpublished data). The $\mathrm{NC}_{2} \mathrm{~A}_{4}-\mathrm{BC}_{3}$ population (i.e. $\mathrm{NCD}_{2}$ at the third backcross stage), however, was found to be less sterile than $81 \mathrm{~A}_{4}$, but as high and stable for male sterility $(0.1-1.0 \%$ pollen shedders) as an $\mathrm{A}_{1}$-system commercial A-line, $841 \mathrm{~A}_{1}(0.2-1.0 \%$ pollen shedders). Thus, it may not be possible to achieve as high levels of sterility in male-sterile populations as in male-sterile A-lines with the $\mathrm{A}_{4}$ cytoplasm. However, developing stable male-sterile populations with the $\mathrm{A}_{4}$ system is at least as feasible as developing commercial male-sterile A-lines with the $\mathrm{A}_{1} \mathrm{CMS}$ system. Further studies with populations of different genetic backgrounds will be required to validate the efficacy of this approach in breeding stable male-sterile populations.

In addition to developing a male-sterile population, there is an important point related to the maintenance of male sterility in populations that must be resolved. The morphological uniformity of inbred male-sterile lines permits easy detection of genetic contaminants and seed admixture in seed production plots. This would be rather difficult to achieve in heterogeneous (morphologically variable) male-sterile populations. Breeding 
dwarf male-sterile populations $(<1.3 \mathrm{~m}$ height $)$ can help manage this problem to some extent. Since pollinator populations will need to be medium to tall $(1.5-2.0 \mathrm{~m})$ to produce hybrids of the desired height for African agricultural situations, any contamination or mechanical admixtures from such populations can easily be detected in dwarf populations during the preflowering stage, to permit timely and effective roguing. Management of this problem can be made even more efficient by introducing easily identifiable recessively inherited seedling markers in male-sterile populations. One such recessively inherited marker gene that produces yellowish seedlings, which later change to green foliage colour during the post-flowering period (Rai et al. 1995b), is currently being introduced into the $\mathrm{NCD}_{2}$ male-sterile population.

\section{Acknowledgements}

Part of this work was done while KNR was a visiting scientist at the University of Nebraska, Lincoln, USA. Partial funding support from Maharashtra Hybrid Seeds Co. Pvt. Ltd. and INTSORMIL is gratefully acknowledged.

\section{References}

Aken'Ova, M. E., 1982: Male sterility in Nigerian bulrush millets (Pennisetum americanum (L.) K. Schum). Euphytica 31, 161-165.

Anand Kumar, D. J. Andrews, R. P. Jain, and S. D. Singh, 1984: ICMA1 and ICMB-1 pearl millet parental lines with A1 cytoplasmic-genic male sterility system. Crop Sci. 24, 832.

Anand Kumar, K., B. Ouendeba, S. Boureima, S. C. Gupta, and S. Ouattara, 1999: Current status of hybrid pearl millet in West Africa. Proc. West African Hybrid Sorghum and Pearl Millet Seed Workshop, 28 September-2 October 1998, Niamey, INRAN/ INTSORMIL/ICRISAT, in press.

Andrews, D. J., and J. F. Rajewski, 1994: Male fertility restoration and attributes of the $\mathrm{A}_{4}$ cytoplasmic-nuclear male sterile system for grain production in pearl millet. Int. Sorghum Millets Newsl. 35, 64.

Athwal, D. S., 1965: Hybrid bajra-1 marks a new era. Indian Farmg. $15,6-7$.

Burton, G. W., 1965: Pearl millet Tift 23A released. Crops and Soils 17, 19.

Burton, G. W., 1974: Factors affecting pollen movement and natural crossing in pearl millet. Crop Sci. 14, 802 - 805.

Chopra, K. R., R. Chopra, G. Rabbani, and K. K. Thimaiah, 1999: Seed production. In: J. J. Khairwal, K. N. Rai, D. J. Andrews, and G. Harinarayana (eds), Pearl Millet Breeding, pp. 445-478. Oxford \& IBH, New Delhi.
Du, R. H., K. N. Rai, and A. S. Rao, 1996: Inheritance of male fertility restoration in pearl millet. Int. Sorghum Millets Newsl. 37, 76.

Genstat, 5 Committee, 1993: Lawes Agricultural Trust, Genestat 5 Release 3.1. Clarendon Press, Oxford.

Hanna, W. W., 1989: Characteristics and stability of a new cytoplasmicnuclear male-sterile source in pearl millet. Crop Sci. 29, 1457-1459.

Hash, C. T., 1997: Research on downy mildew of pearl millet In: M. C. S. Bantilan, and P. K. Joshi (eds), Integrating Research Evaluation Efforts: Proc. Int. Workshop, 14-16 Dec. 1994, Patancheru, 121128. ICRISAT, Patancheru.

Hash, C. T., J. R. Witcombe, R. P. Thakur, S. K. Bhatnagar, S. D. Singh, and J. P. Wilson, 1997: Breeding for pearl millet disease resistance. Proc. Int. Conf. on Genet. Improv. Sorghum and Pearl Millet, 22-27 Sep. 1996, Lubbock, 337-372.

Lambert, C., 1983: L'IRAT et l'amelioration du mil. L'Agron. Trop. 38, $78-88$.

Ouendeba, B., G. Ejeta, W. E. Nyquist, W. W. Hanna, and A. Kumar, 1993: Heterosis and combining ability among African pearl millet landraces. Crop Sci. 33, 735-739.

Peacock, J. M., P. Soman, R. Jayachandran, A. U. Rani, C. J. Howarth, and A. Thomas, 1993: Effects of high soil surface temperature on seedling survival in pearl millet. Exp. Agric. 29, 215-225.

Rai, K. N., 1990: Development of high-yielding dwarf composites of pearl millet. Crop Improv. 17, 96-103.

Rai, K. N., D. J. Andrews, and A. S. Rao, 1995a: Registration of $\mathrm{NCD}_{2}$ pearl millet germplasm. Crop Sci. 35, 1237-1238.

Rai, K. N., A. S. Rao, and C. T. Hash, 1995b: Registration of pearl millet parental lines ICMA 88004 and ICMB 88004. Crop Sci. 35, 1242.

Rai, K. N., D. S. Virk, G. Harinarayana, and A. S. Rao, 1996: Stability of male-sterile sources and fertility restoration of their hybrids in pearl millet. Plant Breeding 115, 494-500.

Rai, K. N., K. Anand Kumar, D. J. Andrews, S. C. Gupta, and B. Ouendeba, 1997: Breeding pearl millet for grain yield and stability. Proc. Int. Conf. on Genet. Improv. Sorghum and Pearl Millet, 22 27 Sep. 1996, Lubbock, 71-83.

Singh, S. D., P. Singh, K. N. Rai, and D. J. Andrews, 1990: Registration of ICMA 841 and ICMB 841 pearl millet parental lines with A1 cytoplasmic-genic male sterility system. Crop Sci. 30, 1378.

Singh, S. D., J. P. Wilson, S. S. Navi, B. S. Talukdar, D. E. Hess, and K. N. Reddy, 1997: Screening Techniques and Sources of Resistance to Downy Mildew and Rust in Pearl Millet. Inf. Bull., No. 48. ICRISAT, Patancheru.

Thakur, R. P., and R. J. Williams, 1980: Pollination effects on pearl millet ergot. Phytopathology 70, $80-84$.

Virk, D. S., 1988: Biometrical analysis in pearl millet - a review. Crop Improv. 15, 1-29. 